\title{
PENGARUH PENEMPATAN DAN MOTIVASI KERJA TERHADAP KEPUASAN KERJA DAN KINERJA GURU DI MADRASAH ALIYAH SE-KABUPATEN JEMBER
}

\author{
Nur Rohim \\ Pascasarjana s2 MPI IAIN Jember \\ rohimachim91@gmail.com \\ Khotibul Umam \\ IAIN Jember \\ khotibulumam.ma@gmail.com
}

DOI: https://doi.org/10.35719/jieman.v2i2.21

\begin{abstract}
Abstrak
Penelitian ini bertujuan untuk mengetahui pengaruh penempatan dan motivasi kerja terhadap kepuasan kerja dan kinerja guru di Madrasah Aliyah Se-Kabupaten Jember. Jumlah populasi 97 Madrasah dengan rincian tiga Madrasah Aliyah Negeri dan 94 Madrasah Aliyah Swasta. Jumlah sampel sebanyak enam madrasah dengan 100 responden. Teknik pengambilan sampel menggunakan purposive sampling. Metode penelitian menggunakan pendekatan kuantitatif jenisnya regresi. Pengumpulan data menggunakan teknik observasi, angket dan dokumendokumen. Analisis data menggunakan Path Analyisis. Data diolah dengan menggunakan program SPSS 16 for Windows. Penelitian sampai pada simpulan: Koefisien jalur pertama, penempatan berpengaruh positif dan signifikan terhadap kepuasan kerja guru serta kepuasan kerja guru juga berpengaruh positif dan signifikan terhadap kinerja guru. Jadi pengaruh langsung penempatan terhadap kinerja guru lebih efektif dari pada melalui kepuasan kerja. Koefisien jalur kedua, motivasi kerja berpengaruh tidak langsung terhadap kinerja guru. Akan tetapi motivasi berpengaruh positif dan signifikan terhadap kepuasan kerja. Jadi pengaruh motivasi kerja terhadap kinerja guru dapat melalui kepuasan kerja guru.
\end{abstract}

Kata Kunci: penempatan, motivasi kerja, kepuasan kerja, kinerja guru 


\begin{abstract}
This study aims to determine the effect of placement and work motivation on job satisfaction and teachers' performance in Madrasah Aliyah throughout Jember Regency. The total population is 97 madrasas consisting of three States and 94 private Madrasah Aliyahs. There are 100 research respondents incorporating six madrasahs in total. The sampling technique used was purposive sampling. This study used a regression type of quantitative approach. Data were collected through observation, questionnaires, and documentation, and then analyzed by using Path Analysis. The data were processed using SPSS 16 for Windows. Based on the results of the analysis and discussion, it can be concluded that; the first Path Coefficient, the placement, has a positive and significant effect on teachers' job satisfaction and the job satisfaction itself also has a positive and significant effect on teachers' performance. Hence, the direct effect of placement on teacher performance is more effective than job satisfaction. The second path coefficient, work motivation, has an indirect effect on teachers' performance. However, motivation has a positive and significant effect on job satisfaction. Therefore, the influence of work motivation on teachers' performance can be measured through teachers' job satisfaction.
\end{abstract}

Keywords: placement, work motivation, job satisfaction teachers' performance

\title{
Pendahuluan
}

Manajemen sumber daya manusia (SDM) pada prinsipnya memuat langkah-langkah perencanaan, rekrutmen, seleksi, pengembangan, pemeliharaan, dan pemanfaatan SDM untuk mencapai tujuan tertentu, baik tujuan perseorangan maupun tujuan organisasi. ${ }^{1}$ Tuntutan terhadap upaya peningkatan mutu pendidikan pada hakikatnya berdampak pada perlunya lembaga pendidikan memiliki SDM yang bermutu, baik pendidik maupun tenaga kependidikan agar mampu berkinerja secara optimal. Manajemen SDM sangat penting peranannya dalam suatu organisasi termasuk dalam lembaga pendidikan seperti sekolah yang juga membutuhkan pengelolaan pendidik dan tenaga kependidikan yang efektif dalam meningkatkan kinerja sekolah itu sendiri. $^{2}$

${ }^{1}$ Pandi Afandi, Manajemen Sumber Daya Manusia Teori, Konsep Dan Indikator (Pekan Baru: Zanafa Publishing, 2018), 23.

${ }^{2}$ Jamil Suprihatiningrum, Guru Profesional Pedoman Kinerja, Kualifikasi $\mathcal{E}$ Kompetensi Guru (Yogjakarta: Ar Ruzz Media, 2013), 171. 
Dalam mengelola SDM pendidikan seperti guru dilaksanakan oleh kepala sekolah. Di dalam Permendiknas nomor 13 tahun 2007 tentang Standar Kepala Sekolah/Madrasah ditegaskan bahwa kompetensi kepala sekolah/madrasah terdiri atas kompetensi kepribadian, kompetensi manajerial, kompetensi kewirausahaan, kompetensi supervisi dan kompetensi sosial. ${ }^{3}$ Dari beberapa kompetensi kepala sekolah tersebut, salah satu yang berhubungan erat dengan pengelolaan SDM pendidikan adalah kompetensi manajerial. Kompetensi manajerial yakni memusatkan pada fungsi, tugas dan sikap kepala sekolah sebagai pemimpin. ${ }^{4}$

Salah satu tugas seorang kepala sekolah dalam mengimplementasikan kompetensi manajerial adalah menempatkan guru yang tepat pada pekerjaan yang tepat. Penempatan merupakan penyesuaian antara tugas guru dengan kompetensi yang dimilikinya. Robert L. Mathis dalam Human Resource Management menegaskan penempatan merupakan proses pencocokan seseorang ke dalam pekerjaan yang tepat. Penempatan SDM harus diapndang khususnya sebagai proses pencocokan yang dapat mempengaruhi pekerjaan yang dengan hasil yang maksimal. Semakin tepat karyawan dicocokkan dengan pekerjaan maka dapat mempengaruhi jumlah dan mutu kinerja personalia tersebut. Yang pada akhirnya, semangat kerja karyawan dapat dipengaruhi karena pencocokan yang baik dapat mendorong individu untuk menjadi lebih baik terkait dengan pencapaian tujuan dalam pekerjaan tersebut. ${ }^{5}$

Prinsip dalam penempatan seseorang dalam menjalankan tugasnya adalah the right man on the right place, orang yang tepat di tempat yang tepat. ${ }^{6}$ Artinya, ketika guru diberikan tugas sesuai dengan bidang keahliannya maka hasil kerjanya akan semakin optimal sehingga tujuan lembaga semakin mudah untuk dicapai.

${ }^{3}$ Sekretariat Negara RI, Peraturan Menteri Pendidikan Nasional Republik Indonesia (Permendiknas RI) nomor 13 tahun 2007 tentang Standar Kepala Sekolah/ Madrasah (Jakarta: Sinar Grafika, 2014), 225-227.

${ }^{4}$ Ahmadi H. Syukran Nafis, Manajemen Pendidikan Islam (Yogyakarta: LaksBang PRESSIndo, 2012), 146.

${ }^{5}$ Robert L. Mathis, Human Resource Management (USA: Thomson South Western, 2008), 226.

${ }^{6}$ Suwatno \& Donni Juni Priansa, Manajemen SDM Dalam Organisasi Publik dan Bisnis (Bandung: Alfabeta, 2014), 97. 
Selain menempatkan guru pada tugas yang sesuai, tugas seorang kepala sekolah juga memberikan motivasi kerja kepada guru. Dalam hal ini, Dale H. Schunk menyatakan bahwa motivasi adalah suatu proses dimulainya dan dipertahankannya aktivitas yang diarahkan pada pencapaian tujuan. Lebih lanjut dijelaskan motivasi merupakan sebuah proses ketimbang sebuah hasil. Sebagai suatu proses, kita tidak secara langsung mengamati motivasi, tetapi kita menarik benang merah motivasi itu dari berbagai aksi (seperti: pilihan tugas, usaha, ketangguhan) dan verbalisasi (misalnya: saya benar-benar mau melaksanakan pekerjaan ini). ${ }^{7}$

Seorang yang termotivasi bekerja keras, mempertahankan langkah kerja keras dan memiliki perilaku yang dikendalikan sendiri ke arah sasaran-sasaran penting. Motivasi mencakup upaya, pantang mundur dan sasaran. Motivasi melibatkan keinginan seseorang untuk menunjukkan kinerjanya ${ }^{8}$. Motivasi kerja merupakan unsur psikologis bagi seorang guru untuk mencapai keberhasilan dalam mengajar. Guru yang tidak mempunyai motivasi mengajar tidak akan berhasil dalam mengajar. Guru memiliki motivasi karena terpenuhi kebutuhan-kebutuhanya yang timbul akibat dari hubungannya dengan sekolah. ${ }^{9}$

Madrasah merupakan kelanjutan dari lembaga pendidikan Islam awal (baca: pondok pesantren) yang mempunyai keseimbangan antara visi duniawi (penguasaan sains dan teknologi) dan visi ukhrawi. Madrasah juga dilihat lebih komprehensif daipada lembaga pendidikan umum yang dinilai kurang memenuhi tuntutan kebutuhan peserta didik, terutama aspek spiritualnya. Oleh karenanya, madrasah sebagai bagian dari penyelenggaraan pendidikan nasional, saat ini juga dituntut mampu melakukan penyelenggaraan pendidikan yang sesuai dengan standar nasional pendidikan yang sudah ditetapkan.

Akan tetapi masih ditemukan beberapa problematika pada madrasah antara lain: Pertama, problem kepemimpinan. Problem kepemimpinan dalam pendidikan Islam (madrasah) meliputi kuantitas (yang sudah menjadi kepala sekolah maupun calon-calon

7 Dale H. Schunk, Paul R. Pintrich, Judith L. Meece, Motivation In Education (New Jersey: Pearson Education, Inc, 2008), 4.

${ }^{8}$ James L. Gibson, dkk. Manajemen Edisi Ke Sembilan, Alih Bahasa: Zuhad Ichyaudin (Jakarta: Erlangga, 1997), 340.

${ }^{9}$ Pupuh Fathurrohman \& Aa Suryana, Guru Profesional (Bandung: PT. Refika Aditama, 2012), 53. 
yang mesti disiapkan), kualitas (kualifikasi akademik minimal yang dipersyaratkan) dan kapabilitas (kemampuan manajerial yang diperlukan untuk menjadikan pendidikan Islam efektif dan sukses). Sebagian mereka adalah lulusan sarjana strata 1 (S-1) baru (bahkan banyak yang diperoleh dalam jabatan) sehingga kurang memenuhi kualifikasi dan kompetensi sebagai pimpinan. Kedua, problem SDM. problem ini menyangkut kuantitas dan kualifikasi akademik para pendidik dan tenaga kependidikan. ${ }^{10}$

Salah satu fungsi kepala madrasah adalah sebagai motivator. Dalam hal ini kepala madrasah berkewajiban untuk memotivasi seluruh pendidik dan juga tenaga pendidikan dalam rangka meningkatkan kepuasan kerja dan kinerja pendidik dan tenaga kependidikan. Untuk pelaksanaan motivasi kerja dari kepala madrasah aliyah kepada guru di kabupaten jember kurang optimal.

Setelah muncul penetapan standar kelulusan mulai tahun 2003 sampai tahun 2019 pada sekolah dan madrasah terhadap nilai mata pelajaran yang diujikan dalam ujian nasional menjadikan bergesernya perhatian kepala madrasah. Banyak lembaga pendidikan memberi jam tambahan pada mata pelajaran yang akan diujikan secara nasional, sehingga perhatian kepala sekolah mulai tertuju pada optimalisasi mata pelajaran yang akan diujikan secara nasional. Dampak kebijakan standar kelulusan tersebut sangat dirasakan oleh guru pengampu mata pelajaran yang lain." Motivasi kepala sekolah terhadap para guru menjadi tidak merata.

Temuan awal di lapangan, ada kepala madrasah yang tidak melaksanakan penempatan sesuai dengan ijazah yang dimiliki guru. Ditemukan juga ada kepala madrasah yang hanya mementingkan pengampu mata pelajaran tertentu dan mengesampingkan mata pelajaran yang lain, sehingga motivasi dari kepala madrasah hanya ditujukan kepada guru mata pelajaran tertentu terutama pelajaran yang di uji nasionalkan, bahkan akan memberikan reward kepada guru mata pelajaran ujian nasional, jika siswa-siswinya ada yang mendapat nilai tertinggi dalam ujian nasional. Meskipun demikian peneliti melihat bahwa guru mata pelajaran yang lainnya ada guru yang mempunyai kepuasan kerja yang tinggi dan kepuasan kerja yang rendah dalam melaksanakan tugas yang mulia tersebut. Ada

${ }^{10}$ Ahmadi H. Syukran Nafis, Manajemen Pendidikan Islam (Yogyakarta: LaksBang PRESSIndo, 2012), 11.

${ }^{11}$ Beni Ahmad Saebani, Ilmu Pendidikan Islam (Bandung: Pustaka Setia, 2012), 219-220. 
pula yang kinerjanya maksimal ada juga yang belum maksimal kinerjanya.

Terkait dengan teori itu, penelitian ini hendak menguji pengaruh penempatan dan motivasi kerja terhadap kepuasan kerja dan kinerja guru Madrasah Aliyah Se-Kabupaten Jember. Penelitian ini menggunakan pendekatan kuantitatif, kerena pada penelitian ini menguji teori dan mengukur pengaruh dari beberapa variabel yang meliputi penempatan, motivasi kerja guru, kepuasan kerja guru dan kinerja guru dalam bentuk perhitungan presentase, perhitungan statistik dan perbandingan koifisien, sehingga lebih tepat jika menggunakan pendekatan kuantitatif.

Jenis penelitian ini adalah penelitian regresi, yaitu penelitian dengan model hubungan antara dua variabel atau lebih. Teknik pengambilan sampel dalam penelitian ini menggunakan proportional stratified random sampling yaitu pengambilan sampel secara acak berdasarkan tingkatan dari populasi dengan prosentase yang sama. Sebagaimana tabel berikut:

Tabel 1

Data Sampel Penelitian ${ }^{12}$

\begin{tabular}{|l|l|l|l|l|l|}
\hline No. & Lembaga & Populasi & $\begin{array}{l}\text { Pengambilan } \\
\text { Sampel }\end{array}$ & Hasil & $\begin{array}{l}\text { Jumlah } \\
\text { Sampel }\end{array}$ \\
\hline 1. & MAN 1 Jember & 76 & $76 / 293 \times 100$ & 25,94 & 26 \\
\hline 2. & MAN 2 Jember & 59 & $59 / 293 \times 100$ & 20,14 & 20 \\
\hline 3. & MAN 3 Jember & 54 & $54 / 293 \times 100$ & 18,43 & 18 \\
\hline $4 \cdot$ & $\begin{array}{l}\text { MAS Ma'arif } \\
\text { NU Kencong }\end{array}$ & 34 & $34 / 293 \times 100$ & 11,60 & 12 \\
\hline $5 \cdot$ & $\begin{array}{l}\text { MAS Darus } \\
\text { Sholah Jember }\end{array}$ & 32 & $32 / 293 \times 100$ & 10,92 & 11 \\
\hline 6. & $\begin{array}{l}\text { MAS Nuris } \\
\text { Jember }\end{array}$ & 38 & $38 / 293 \times 100$ & 12,97 & 13 \\
\hline \multicolumn{2}{|l}{ Jumlah Sampel } & 293 & 100 & 100 & 100 \\
\hline
\end{tabular}

Data primer diperoleh langsung dari responden yang berupa informasi yang diperoleh dari jawaban kuisioner responden sebanyak 100 guru Madrasah Aliyah se-Kabupaten Jember.

${ }^{12}$ Sumber Data populasi guru Madrasah Aliyah tahun pelajaran 2018/2019 


\section{Pembahasan}

\section{Penempatan Berpengaruh terhadap Kepuasan Kerja Guru}

Hasil analisis disebutkan bahwa koefisien jalur penempatan berpengaruh terhadap kepuasan kerja guru sebesar 0,292 dengan nilai Sig sebesar 0,002 < 0,05 probabilitas. Hal ini menunjukkan adanya pengaruh yang signifikan antara penempatan ( $\left.\mathrm{X}_{1}\right)$ terhadap kepuasan kerja (Y). Koefisien jalurnya menunjukkan bahwa penempatan berpengaruh signifikan terhadap kepuasan kerja guru artinya semakin tepat penempatan guru maka kepuasan kerja guru akan semakin meningkat.

Hal ini memperkuat pendapat Wibowo bahwa apabila penempatan yang dilakukan tepat maka akan mengahasilkan kepuasan yang baik bagi guru maupun sekolah. ${ }^{13}$ Hal serupa dikemukakan oleh Hasibuan. Menurutnya, salah satu faktor kepuasan kerja personel dipengaruhi oleh penempatan yang tepat sesuai dengan keahliannya. ${ }^{14}$ Hasil temuan ini sekaligus memperkuat hasil penelitian Benni Yulizar dengan hasil terdapat hubungan yang berarti antara penempatan dengan kepuasan kerja pegawai. ${ }^{15}$

\section{Penempatan Berpengaruh terhadap Kinerja Guru}

Hasil analisis disebutkan bahwa koefisien jalur penempatan berpengaruh terhadap kinerja guru sebesar 0,403 dengan nilai Sig sebesar $0,02>0,05$ probabilitas, hal ini menunjukkan adanya pengaruh yang signifikan antara penempatan $\left(\mathrm{X}_{1}\right)$ terhadap kinerja guru (Z). Koefisien jalurnya menunjukkan bahwa penempatan berpengaruh signifikan terhadap kinerja guru artinya semakin tepat penempatan guru maka kinerja guru akan semakin meningkat.

Mathis dan Jackson mengemukakan bahwa penempatan adalah menempatkan posisi seseorang ke posisi pekerjaan yang tepat, seberapa baik seorang karyawan cocok dengan pekerjaanya akan memengaruhi kuantitas dan kualitas pekerjaan. ${ }^{16}$ Hasil

${ }^{13}$ Wibowo, Manajemen Kinerja (Jakarta: Raja Grafindo Persada, 2012), 501

${ }^{14}$ S.P, Melayu Hasibuan, Manajemen: Dasar, Pengertian dan Masalah (Jakarta: Bumi Aksara, 2011) 203.

${ }^{15}$ Benni Yulizar, "Hubungan Penempatan dan Kepuasan Kerja Pegawai pada Kantor Dinas Sosial Provinsi Sumatra Barat”. Bahana Manajemen Pendidikan 2 (1), Juni 2014, 92-99

${ }^{16}$ Robert L. Mathis, Human Resource Management (USA: Thomson South Western, 2008), 226 
temuan ini memperkuat hasil penelitian Christina Wynda Deswarati bahwa penempatan berpengaruh positif dan signifikan terhadap kinerja karyawan. ${ }^{17}$

\section{Motivasi Berpengaruh terhadap Kepuasan Kerja Guru}

Hasil analisis disebutkan bahwa koefisien jalur motivasi berpengaruh terhadap kepuasan kerja guru sebesar o,510 dengan nilai Sig sebesar 0,000 < 0,05 probabilitas menunjukkan adanya pengaruh yang signifikan antara motivasi kerja ( $\left.\mathrm{X}_{2}\right)$ terhadap kepuasan kerja (Y). Koefisien jalurnya menunjukkan bahwa motivasi kerja berpengaruh signifikan terhadap kinerja guru artinya semakin tinggi pemberian motivasi kerja maka kepuasan kerja guru akan semakin meningkat.

Hasil ini sejalan dengan teori yang disampaikan oleh Rivai bahwa relasi motivasi terhadap kepuasan kerja adalah jika seseorang termotivasi, dia akan membuat pilihan yang positif untuk melakukan sesuatu, karena dapat memuaskan keinginan dirinya. ${ }^{18}$ Handoko juga mengemukakan bahwa motivasi yang ada pada diri seseorang merupakan kekuatan pendorong yang mewujudkan suatu perilaku guna mencapai tujuan kepuasan dirinya. ${ }^{19}$ Hal ini sekaligus memperkuat penelitian Atep Afia dan Achmad Kasful Anwar bahwa motivasi memiliki pengaruh signifikan terhadap kepuasan kerja. Semakin baik motivasi guru maka semakin baik kepuasan kerja. ${ }^{20}$

\section{Motivasi Kerja Berpengaruh terhadap Kinerja Guru}

Hasil analisis disebutkan bahwa koefisien jalur motivasi berpengaruh terhadap kinerja guru sebesar -0,045 dengan nilai Sig sebesar $0,749>0,05$ probabilitas menunjukkan adanya pengaruh yang tidak signifikan antara motivasi kerja $\left(\mathrm{X}_{2}\right)$ terhadap kinerja

${ }^{17}$ Christina Wynda Deswarati, "Pengaruh Penempatan Terhadap Motivasi Kerja Dan Kinerja Karyawan (Studi Pada Karyawan PT. Astra International, Tbk-daihatsu Malang)." Jurnal Administrasi Bisnis 4 (2) (2013), 11

${ }^{18}$ Veithzal Rivai, Manajemen Sumber Daya Manusia untuk Perusahaan (Teori dan Praktek) (Jakarta: Murai Kencana, 2004), 456.

${ }^{19}$ T. Hani Handoko, Manajemen Personalia dan Sumber Daya Manusia (Yogyakarta: BPFE, 2013), 194.

${ }^{20}$ Atep Afia dan Achmad Kasful Anwar, "Pengaruh Motivasi terhadap Kepuasan Kerja Guru dan Karyawan Pada Unit SMP Yayasan Pendidikan Dharma Putra”. Sinergi, 290-299 
guru (Z). Koefisien jalurnya menunjukkan bahwa semakin tinggi motivasi tidak akan membawa pengaruh terhadap kinerja guru.

Berdasarkan data tentang deskripsi tentang identitas responden berdasarkan usia, mayoritas dari responden adalah guru yang berusia $41-50$ tahun (40\%). Hal ini berarti menujukkan bahwa guru senior lebih sulit diatur dibandingkan dengan guru junior, sehingga mereka merasa bahwa motivasi tidak terlalu penting untuk meningkatkan kinerja mereka.

Secara teoritis, hasil penelitian ini memperkuat teori Hamzah B. Uno bahwa motivasi kerja merupakan salah satu faktor yang ikut menentukan kinerja individu. Besar-kecilnya pengaruh motivasi pada kinerja individu tergantung pada seberapa banyak intensitas motivasi yang diberikan. Perbedaan motivasi kerja bagi guru biasanya terejawantahkan dalam berbagai kegiatan dan bahkan prestasi yang dicapainya. ${ }^{21}$ Selain itu, penelitian ini juag sejalan dengan hasil penelitian Siti Markonah dan Sunarto bahwa motivasi tidak berpengaruh positif dan signifikan terhadap kinerja guru. $^{22}$

\section{Kepuasan Kerja Berhubungan dengan Kinerja Guru}

Hasil analisis disebutkan bahwa koefisien jalur kepuasan kerja berhubungan dengan kinerja guru sebesar o,340 dengan nilai Sig sebesar 0,001 < 0,05 probabilitas menunjukkan adanya pengaruh yang signifikan antara kepuasan kerja (Y) terhadap kinerja guru (Z). Koefisien jalurnya menunjukkan bahwa semakin tinggi kepuasan kerja maka semakin tinggi kinerja guru.

Secara teoretis, Hasibuan menyampaikan bahwa kepuasan kerja (job satisfaction) adalah sikap emosional yang menyenangi dan mencintai pekerjaannya. Sikap ini diekspresikan oleh etika kerja, kedisiplinan dan prestasi kerja. Kepuasan kerja dalam pekerjaan merupakan kepuasan kerja yang dinikmati dalam pekerjaan dengan memperoleh hasil pujian hasil kerja, penempatan,

${ }^{21}$ Hamzah B. Uno, Teori Motivasi Dan Pengukurannya Analisis Dibidang Pendidikan (Jakarta: Bumi Aksara, 2013), 71.

${ }^{22}$ Siti Markonah dan Sunarto, "Pengaruh Motivasi dan Kompetensi terhadap Kinerja Guru Dimediasi Komitmen Organisasional (Studi Kasus di SMA Negeri 1 Jakenan Kabupaten Pati)," (Semarang: Universitas Stikubank Semarang, 2014), 1-20. 
perlakuan, sarana-prasarana dan suasana lingkungan kerja yang kondusif. ${ }^{23}$

Pandi Afandi juga mengatakan bahwa terdapat hubungan positif antara kepuasan kerja terhadap kinerja. ${ }^{24}$ Hal ini sesuai dengan penelitian Oxy Rindiatika Sari dan Heru Susilo bahwa kepuasan kerja berpengaruh terhadap kinerja pegawai. ${ }^{25}$

\section{Penempatan Melalui Kepuasan Kerja Berpengaruh Positif dan Signifikan terhadap Kinerja Guru}

Hasil analisis dan perhitungan menunjukkan bahwa penempatan berpengaruh positif dan signifikan terhadap kepuasan kerja guru dan kepuasan kerja guru juga berpengaruh positif dan signifikan terhadap kinerja guru. Pengaruh langsung penempatan terhadap kinerja guru lebih efektif dari pada melalui kepuasan kerja. Artinya pengaruh penempatan kerja terhadap kinerja guru tidak dapat melalui kepuasan kerja.

Sebagaimana pendapat Hasibuan, salah satu faktor kepuasan kerja personel dipengaruhi oleh penempatan yang tepat sesuai dengan keahliannya. Dan kepuasan kerja tercermin oleh prestasi kerja yang dicapai. Maka dapat dirumuskan penempatan berpengaruh melalui kepuasan kerja terhadap kinerja guru. ${ }^{26}$

\section{Motivasi Kerja Melalui Kepuasan Kerja Berpengaruh terhadap Kinerja Guru}

Hasil analisis dan perhitungan menunjukkan bahwa motivasi berpengaruh positif dan signifikan terhadap kepuasan kerja akan tetapi motivasi tidak berpengaruh positif dan siginifikan terhadap kinerja guru. Pengaruh tidak langsung motivasi kerja terhadap kinerja guru lebih efektif dari pada pegaruh langsung motivasi kerja terhadap kinerja guru. Artinya pengaruh motivasi kerja terhadap kinerja guru dapat melalui kepuasan kerja guru.

${ }^{23}$ SP, M. Hasibuan, Manajemen Sumber Daya Manusia, Edisi Revisi, Cetakan ke-sepuluh, (Jakarta: Bumi Aksara, 2012), 202.

${ }^{24}$ Pandi Afandi, Manajemen Sumber Daya Manusia Teori, Konsep Dan Indikator (Pekan Baru: Zanafa Publishing, 2018), 78.

${ }^{25}$ Oxy Rindiatika Sari dan Heru Susilo, "Pengaruh Kepuasan Kerja terhadap Kinerja Karyawan dengan Organizational Citizenship Behavior sebagai Variabel Intervening, Jurnal Administrasi dan Bisnis Universitas Brawijaya Malang, 64 (1), November 2018, 28-35.

${ }^{26}$ SP, M. Hasibuan, Manajemen Sumber Daya Manusia, Edisi Revisi, Cetakan ke-sepuluh, (Jakarta: Bumi Aksara, 2012), 202. 
Hasil ini mengonfirmasi pendapat Rivai bahwa hubungan motivasi terhadap kepuasan kerja adalah jika seseorang termotivasi, maka dia akan membuat pilihan yang positif untuk melakukan sesuatu, karena dapat memuaskan keinginan dirinya. Hasibuan, mengatakan kepuasan kerja tercermin oleh prestasi kerja yang dicapai. Maka dapat dirumuskan motivasi kerja berpengaruh melalui kepuasan kerja terhadap kinerja guru. ${ }^{27}$

\section{Simpulan}

Berdasarkan hasil analisis dan pembahasan, maka dalam penelitian ini dapat disimpulkan: Koefisien jalur pertama, Penempatan berpengaruh positif dan signifikan terhadap kepuasan kerja guru serta kepuasan kerja guru juga berpengaruh positif dan signifikan terhadap kinerja guru. Jadi pengaruh langsung penempatan terhadap kinerja guru lebih efektif dari pada melalui kepuasan kerja. Koefisien jalur kedua, motivasi kerja berpengaruh tidak langsung terhadap kinerja guru. Akan tetapi motivasi berpengaruh positif dan signifikan terhadap kepuasan kerja. Jadi pengaruh motivasi kerja terhadap kinerja guru dapat melalui kepuasan kerja guru.

\section{Referensi}

Afandi, Pandi. Manajemen Sumber Daya Manusia Teori, Konsep Dan Indikator. Pekan Baru: Zanafa Publishing, 2018.

Afia, Atep, and Achmad Kasful Anwar. "Pengaruh Motivasi terhadap Kepuasan Kerja Guru dan Karyawan pada Unit SMP Yayasan Pendidikan Dharma Putra." Sinergi 17 (3) 2013: 290299.

Deswarati, Christina Wynda. "Pengaruh Penempatan terhadap Motivasi Kerja dan Kinerja Karyawan.” Jurnal Administrasi Bisnis 4 (2) 2013, 1-11.

Fathurrohman, Pupuh \& Aa Suryana. Guru Profesional. Bandung: PT. Refika Aditama, 2012.

Gibson, James L. et.al. Manajemen. Alih Bahasa: Zuhad Ichyaudin. Jakarta: Erlangga, 1997.

${ }^{27}$ Veithzal Rivai, Manajemen Sumber Daya Manusia untuk Perusahaan (Teori dan Praktek), (Jakarta: Murai Kencana, 2004), 456. 
Handoko, T. Hani. Manajemen Personalia dan Sumber Daya Manusia. Yogyakarta: BPFE, 2013.

Hasibuan, S.P. Melayu. Manajemen: Dasar, Pengertian dan Masalah. Jakarta: Bumi Aksara, 2011.

Markonah, Siti dan Sunarto. "Pengaruh Motivasi dan Kompetensi terhadap Kinerja Guru Dimediasi Komitmen Organisasional (Studi Kasus di SMA Negeri 1 Jakenan Kabupaten Pati.” Tesis, tidak diterbitkan. Semarang: Universitas Stikubank Semarang, 2014.

Mathis, Robert L. Human Resource Management. USA: Thomson South Western, 2008.

Nafis, Ahmadi H. Syukran. Manajemen Pendidikan Islam. Yogyakarta: LaksBang PRESSIndo, 2012.

Rivai, Veithzal. 2004. Manajemen Sumber Daya Manusia untuk Perusahaan (Teori dan Praktek). Jakarta: Murai Kencana.

Saebani, Beni Ahmad. Ilmu Pendidikan Islam. Bandung: Pustaka Setia, 2012.

Sari, Oxy Rindiatika dan Heru Susilo. "Pengaruh Kepuasan Kerja terhadap Kinerja Karyawan dengan Organizational Citizenship Behavior sebagai Variabel Intervening).” Jurnal Administrasi dan Bisnis Universitas Brawijaya Malang, 64 (1), November 2018, 28-35.

Schunk, Dale H., Paul R. Pintrich, and Judith L. Meece. 2008. Motivation in Education. New Jersey: Pearson Education, Inc.

Sekretariat Negara RI. Peraturan Menteri Pendidikan Nasional Republik Indonesia Nomor 13 tahun 2007 tentang Standar Kepala Sekolah/ Madrasah. Jakarta: CV. Sinar Grafika, 2014.

Suprihatiningrum, Jamil. Guru Profesional Pedoman Kinerja, Kualifikasi \& Kompetensi Guru. Yogjakarta: Ar-uzz Media, 2013.

Suwatno \& Donni Juni Priansa. Manajemen SDM Dalam Organisasi Publik dan Bisnis. Bandung: Alfabeta, 2014.

Uno, Hamzah B. Teori Motivasi dan Pengukurannya Analisis di Bidang Pendidikan. Jakarta: Bumi Aksara, 2013.

Wibowo. Manajemen Kinerja. Jakarta: Raja Grafindo Persada, 2012.

Yulizar, Benni. "Hubungan Penempatan dan Kepuasan Kerja Pegawai pada Kantor Dinas Sosial Provinsi Sumatera Barat." Bahana Manajemen Pendidikan, 2 (1), Juni 2014, 92-99. 